\title{
Using Group Method of Teaching to Address the Problem of Large Class Size: An Action Research
}

\author{
Emmanuel Kofi Mintah \\ Head of I.C.T. Department, S.D.A. Senior High School, Bekwai-Ashanti, Ghana \\ Master of Business Administration (Accounting), Bachelor of Education (Accounting) \\ Current Research Areas: Accounting, Education and I.C.T. \\ E-mail: adontsen@yahoo.com
}

Doi:10.5296/ijld.v4i2.5707

URL: http://dx.doi.org/10.5296/ijld.v4i2.5707

\begin{abstract}
Large class sizes in Ghanaians schools with its attendants problems are major factors for the dwindling academic performance of students in Ghana. To solve this problem would call for reduction in the number of students in classrooms which would deprive some children from their right to education or building more schools and employing more staff which would bloat government expenditure and no government would want to do that. This paper brings to light the best and innovative method of addressing the problem of large class sizes. Test, interview, observation and questionnaires were the main data collection instruments used. The study revealed that Ghanaian schools have large class sizes. The following were identified to be problems of large classes: inappropriate methods of teaching; inappropriate mode of assessment; stifled students' creativity; inattention to students' problems. The research further showed that group method of teaching Financial Accounting is the best way of addressing the problem of large class size. It is recommended that teachers use appropriate method of teaching to motivate, arouse and sustain students' interest in their subjects. Again, school administrators must organize regular in-service training to teachers and also monitor closely the work of teachers and students. Stakeholders of education must institute reward and incentive schemes to motivate teachers to give of their best.
\end{abstract}

\subsection{Background to the study}

Numerous studies have been done to examine the impact of class size on teaching and learning. Majority of these studies have focused on elementary and pre-school levels of education. Few studies have focused on the role that class size play in teaching and learning of Financial Accounting in the second cycle schools.

The number of students in a class has the potential to affect how much is learned in many ways. It could affect how much time the teacher is able to focus on individual students and their specific needs rather than on the group as a whole. Since it is easier to focus on one individual in a smaller group, the smaller the class size, the more likely individual attention can be given.

Studies all over the world indicate that a class size of more than 35 pupils or students compromises quality education. According to the National Association of Graduate Teachers (NAGRAT), Ghana, there is a correlation between the size of a class and the performance of its students and that an over-bloated class size hinders quality teaching and learning. (Daily Graphic, 25 August 2011)

During 2001 evaluation of the Student Achievement Guarantee in Education (SAGE), class size reduction program by researchers at the University of Wisconsin-Milwaukee found that a 
five-year-old program of class-size reduction in Wisconsin resulted in higher achievement for children living in poverty. Research from Columbia University Teachers College in New York showed the context of class-size reduction can affect its success in improving student achievement (Ready, 2008).

Seventh-day Adventist Senior High School established in 1953 as the first second cycle institution of the Seventh-day Adventist church and first second cycle institution in the Bekwai Municipal Assembly hast population of over two thousand eight hundred, and teaching staff of one hundred twenty and auxiliary staff of ninety two. The school is densely populated in relation to the infrastructure it has.

The population, according to the teachers and administrators, has tripled over the last decade but the infrastructure of the school has slightly changed. The high population was attributed to the fact that Ghanaians have come into realization that education is a key to personal and national development. In addition, education is seen as a tool for poverty eradication. Again the government policy to lower the entrant point from aggregate 36 to 42 has allowed more Basic Education Certificate holders to qualify to enter into Senior High Schools. The computer placement system which prevents the heads of Senior High School to set limits for students they can admit is also said to be a factor for high enrolment in Senior High Schools in Ghana.

The researcher was not surprised that the Senior High Schools in Ghana, of which Seventh-day Adventist Senior High School is no exception, had such a high population. This high population has led to large class size.

In a large class situation, as pertained in Seventh-day Adventist Senior High School, before any effective teaching and learning can take place the teacher must design an innovative approach to teaching, hence the adoption of group method of teaching to solve the problem of teaching Financial Accounting in large class.

\subsection{Statement of the problem}

Accounting studies in its broad sense is the medium of educating the individual with regard to: creating an awareness of business, economic and financial problems of the business world, developing an interest and concern for business as a career, acquainting students with institutions and operation of national economy, developing problem solving skills, equipping students with the skill of making maximum use of scarce resources and developing competencies in computational skills. The acquisition of these skills and competencies require a conducive learning atmosphere and appropriate teaching methods. A large class does not give such needed environment. As a result of this, business students of Seventh-day Adventist Senior High School and for that matter, many Senior High Schools in Ghana are likely to perform poorly in standard examinations. Graduates from the schools find it difficult to qualify to enter into any tertiary institution. This can be one of the reasons for the recent rampant examination malpractices that are seen in the educational sector. In addition, it has also discouraged a lot of people from reading accounting courses in recent times.

However reducing class size could bring negative implications on both individuals and the government. It means more schools must be built and the infrastructure of the existing schools must be expanded. Again, more teachers must be trained or forcing schools and districts to hire unqualified or unprepared teachers. This will put pressure on the already tight budgets of the government. To many policymakers in education, the solution to the problem of large class is 
not to reduce class size but to use appropriate teaching methods to increase individual instruction time, such as making learning more of child-centred.

It is therefore in the wake of this that the researcher wishes to examine the problems of teaching Financial Accounting in large class and to see how Group Method of Teaching addresses such problems.

\subsection{Objectives:}

The general objective of the action research is to come out with an innovative method of teaching Financial Accounting in a large class. The specific objectives are to:

1. identify reasons why second cycle schools have high enrolment

2. assess the effect of large class size on the teaching and learning of Financial Accounting

3. determine the extent to which group method of teaching addresses the problem teaching Financial Accounting in large class

4. examine how students' perception about a subject affects their performance in that subject.

\subsection{Research questions}

Several questions need to be addressed in this study. This research was guided by the following:

1. Why do schools have high enrolment?

2. Do large class sizes affect the teaching and learning of financial accounting?

3. To what extent can group method of teaching address the problem of large class size in the teaching of financial accounting?

4. To what extent does students' perception about a subject affect their performance in that subject?

\subsection{Significance of the study}

The researcher believes that the study will add to knowledge by:

1. Motivating, arousing, and sustaining students' interest in the study of financial accounting and perform excellently

2. It will equip teachers of financial accounting with the necessary skills and techniques in teaching financial accounting in large classes

3. Making the school authorities aware of the problems teachers face in handling large class sizes so as to design appropriate strategies to remedy the situation

4. Bringing out knowledgeable and well-endowed personnel for nation building

\section{Scope of the study}

The study was conducted on the first year accounting students of Seventh-day Adventist Senior High School, Bekwai. The researcher selected this school and the class because of proximity and for easy accessibility to data.

\section{Review of Related Literature}

\subsection{Introduction}

The chapter reviews existing literature, which is related to the problem at stake. The chapter tries to look at an ideal class size, the cause of large class sizes in schools, the effect of large class on the teaching and learning, especially on the teaching and learning of financial accounting, and the importance of Group Method of teaching to large class size. 


\subsection{An ideal class}

Class size is not the same thing as the pupil/teacher ratio. Indeed, it is quite different. The calculation of a pupil/teacher ratio typically includes teachers who spend all or part of their day as administrators, librarians, special education support staff, itinerant teachers, or other roles outside the classroom. Thus, pupil/teacher ratio is a global measure of the human resources brought to bear, directly and indirectly, on children's learning. Class size refers to the actual number of pupils taught by a teacher at a particular time. (Ehrenberg et al 2011)

An ideal class, according to Ghana Education Service policy, should have between twenty-five and thirty-five students. When the number of students in a class is more than thirty-five such a class is said to be large. It is interesting to note that the number of students in a class in most Ghanaian Senior High Schools, which Seventh-day Adventist Senior High School is inclusive, on average is sixty five. (Zainul-Deen, 2011)

\subsection{Causes of large class size}

According to Hou (1994), in recent times people believe that education creates social and economic benefits for individuals, families and society. It is principally on this basis many people, young and old, embrace education and justify their efforts to continually improve their qualification and other levels of skills.

The problem of large class size may also be attributed to government's inability to build more schools and expand the facilities of the existing schools to accommodate the increasing number of students in the country. The report of the President's Committee on Review of Education in Ghana (2005), in accounting for the factors contributing to low performance students, made mention of poor infrastructure. It further stated that, the facilities in many Senior High Schools, especially in the community day schools, are inadequate. It recommended that adequate number of classrooms should be provided by the ministry of education to accommodate the increasing number of students.

Pressure from old students' associations, chiefs and opinion leaders on heads of institutions is another reason for large class sizes in our schools. Some parents would want their wards to attend the schools they attended perhaps for the good name the school has made for itself. The chiefs and the opinion leaders in the communities in which the schools are situated think that the only benefit their society could get from the school is to train their citizenry thereby persuade the heads to admit their wards even though the school may be full to its capacity.

In recent times, there has been massive campaign for the need to educate our females. Parents have therefore come to the realization of the importance of sending their girl-child to school. This has contributed to the high enrolment that we see in our secondary schools.

The reduction in the grading system that qualifies one from Junior High School to Senior High School from aggregate 36 to aggregate 42 and the computer placement system which leaves the heads of institution no option than to accept the number of students push to them are other factors causing high enrolment is schools.

Increase in the population of the school-going age is another reason for high enrolment in our schools. There has been a tremendous increase in the population over the last decade meanwhile the school infrastructures have remain almost the same. Education is a right not a 
privilege therefore; every citizen should be given the opportunity. The slogan has then been 'let's make do with what we have' so we have over crowded our students in the few schools we have in the country.

The society is also blamed for the problem of large class sizes in our schools in the sense that, it has not done enough to support the school system by expanding its facilities. School play a crucial role in the transformation process of any society and transformation has been the buzzword in Ghana education since the advent of independence in 1957.

\subsection{Effects of Large Class on Teaching and Learning}

Irrespective of the reasons for the large class sizes in the schools of which SDA Senior High School is among; the quality of education provided by a given institution should not be compromised. The effectiveness of any educational system depends on the production of competent, dedicated and efficient graduates.

The impact of large class on the teaching and learning has had long vigorous research history. One significant issue that appears constantly in many researches is that, when it comes to attainment of higher-order academic skills such as problem solving, written expressions and critical thinking, students in smaller classes do acquire more of these skills than do students in larger classes. (Schiming, 2013)

Mawutor (1999) in his article, 'New teaching Strategies: A case study from the University College of Education Winneba, outlined the following effects of large class sizes on the teaching and learning; insufficient participation of students in class lessons; students sometimes appear to be passive; control tends to be a major problem; feedback from assignments and tests are not effective in the sense that marking of students exercises are usually on periphery; insufficient furniture becomes a problem; and cheating in examinations and class exercises becomes a nagging problem which makes assessment very difficult.

Greyling (1995) stated her point on the issue under consideration by saying, "the situation of large class is impersonal- perhaps even overpowering-when students fill thousands of seats in a large amphitheatre that seemingly dwarfs the lecturer and this result in students' failure". Greyling in her statement attributes students' failure to ineffective methods of teaching due to large class sizes.

Newble and Cannon (1995) stated that large classes are essentially dominated by the lecture method. They therefore mentioned the following problems associated with large classes: it does not allow for critical thing; it stifles students' creativity when activity based and child-centred teaching methods are not used.

According to Farrant (2002), large class is characterized by a method of teaching that is quite unable to allow for any individual differences there might be among the students. He has this to say, 'the weakness of the method (large class) is that it encourages a good deal of passive learning. The teacher is the active member of the unit and, in a normal class the students have only one chance in forty of getting an opportunity to contribute positively to the lesson at any moment. This is far from being an ideal educational practice'.

According to Ornestein and Lasley II (2000), the critics of lecture method in large class, contend it fails to meet the needs and interest of individual students. Teachers who use this method tend to look upon the students as a homogenous group with common abilities, interests, 
styles of learning, and motivation. Instruction is to a hypothetical average student and all students are expected to learn and perform with narrow limits. High-achieving students eventually become bored, and low-achieving students become frustrated. The uniqueness of each student is often lost in the large class. Extroverted students tend to monopolize the teacher's time, and passive students usually are not heard from or do not receive necessary attention. Finally, students sometimes act out their behavioural problems in teacher-centred whole class instructional formats.

Certainly, large class has untold effect on teaching and learning, especially teaching and learning of accounting. I strongly support the assertion made by the above writers. However, when the problem of large class is addressed using innovative approach to teaching, such as group method of teaching, teaching and learning of accounting in S. D. A senior high school would improve and students would do better than they do now.

\subsection{Group Method of Teaching}

Marvin et al (2001) define group as 'persons who are interacting with one another in such a manner that each person influences and is influenced by each other'.

From the above definition, group method of teaching can be described as putting learners into smaller groups to discuss on specific issues or work on specific task in order to achieve some interdependent goal, such as increased understanding, coordination of activities, or a solution to a shared problem.

According to Orstein and Lasley II (2002), dividing students into groups seems to provide an opportunity for students to become more active in learning and for teachers to monitor students' progress better. Between five and eight students seems to be an optimal number.

\subsection{Benefit of Group method of Teaching}

According to Walter (1986), acquisition of skills, attitudes and values can best be done by practice, involving series of activities, therefore, to achieve learning in the category of skills, attitude and values, it is recommended to use the project and group methods.

He enumerated the following as the advantages of group method of teaching: it provides a more relaxed and natural learning situations; it creates situations that favour effective learning; it is problem centred; it can arouse the motivation of many learners in class, especially as one problem normally covers many varieties of interests. He further stated that, group work offers lots of avenues for self-expression and creativity among students. A good deal of social learning, therefore takes place, and every individual in the class is given the opportunity to contribute his or her worth towards group success.

Farrant (2002), in his book 'Principles and Practice of Education', made mention of a lot of advantages that are derived from group method of teaching. Among these are: it gives more students an opportunity to participate actively in the lesson; in skill subjects more students are given the chance to practice for longer times; in a class where students are put in similar ability groups, the slow move at their own pace without hindering the progress of the bright. Where mixed ability grouping is well planned, the brighter students assist the slower students in the group; grouping is the appropriate means of dealing with practical lessons. 


\subsection{Conditions under which group method is appropriate}

According to Farrant (2002) grouping is appropriate means of dealing with practical lessons, such as accounting, for which there is insufficient equipment for every child. This becomes very difficult when the class is large therefore grouping the students is the best way of making impact on the students.

Group method is also appropriate for tackling jobs too big for individuals and too restricting for the whole class. For example, in projects, the task can usually be divided into several parts and one allocated to each group. In such circumstances, the groups enjoy the satisfaction of contributing their part and feel that they are truly involved in the project as a whole.

In addition to the above, group method becomes necessary when the class is large, as in the case of SDA senior High School. In such a large class, in order to identify individual student's problems and then institute right measures to address them you have to put the students into smaller groups during class exercises and project.

According to Sprinthall and Sprinthall (1990), group method is appropriate where students are to discover facts on their own and where creativity is crucial. According to them, it is a means by which students get together in an attempt to solve problems in new and creative ways. In this sense, each participant will individually produce more creative solutions by interacting freely, to call out any ideas no matter how bizarre, and to holding nothing back.

\section{Methodology}

\subsection{Introduction}

This chapter looks at the methodology used to conduct the research. It is composed of the research design, the population of the study, sample size, sampling techniques, instrument used, data analysis procedures and reliability and validity.

\subsection{Research design}

Quantitative and qualitative techniques were used in gathering data because the focus of the research is to design an innovative method of teaching to address the problem of teaching Financial Accounting in a large class. In this wise, assessment were used to determine whether the method had worked or not.

\subsection{Population}

Since the research was on specific course area, Accounting Studies, the population was teachers who teach accounting classes and all the accounting students of the selected school: Seventh-day Adventist Senior School, Bekwai-Ashanti, Ghana

\subsection{Sample size}

Sixty (60) first year accounting students, ten teachers of the business classes and four administrators; the headmistress, the assistant head-domestic, assistant head-academics and senior house master were sampled. The action research was on the accounting students, the business studies teacher and the school administration; therefore it became imperative and prudent to concentrate on such classes or groups. 


\section{M|Macrothink}

\subsection{Sample method}

The researcher used stratified and simple random sampling in choosing the students. For the peculiar nature of information needed from the teachers and administrators, purposive sampling was used.

\subsection{Research instruments}

The researcher used class tests and class exercises as well as questionnaires to gather information. Observation was also used extensively. Class tests and exercises were used to enable the researcher compare pre-intervention performance with post-intervention performance as to whether the intervention has worked or not.

\subsection{Data Analysis Procedures}

For the purpose of easy understanding and simplicity the researcher analysed major statements in the research instrument. The researcher organized the data into tables, charts and percentages because they make for easy reading and understanding. The data collected from the questionnaire were analysed in the following categories:

Teachers -10

Students -60

\subsection{Reliability and validity}

After all questions of the respondents have been addressed and any prejudices have been cleared, they were given the questionnaires to fill independently. Class exercises were conducted on both group and individual bases to confirm results from questionnaires and interviews.

\section{Intervention and data presentation}

\subsection{Intervention}

The intervention was in three stages. The first stage dealt with pre-intervention activities. The second stage was on the intervention executed and the third stage was about the post-intervention implementation stage. Intervention design was based on the information from interviews, observation, class test and exercises conducted, and questionnaires administration.

\subsection{Pre-intervention stage}

After teaching for two months, the researcher realised that teaching financial accounting in a large class was very difficult and if care was not taken teaching of financial accounting, at the end of the day, would be slaughtered on the altar of compromise. This was revealed through the class exercises and a test conducted after two months of teaching, observation made and information gathered from interview.

Based on this, the researcher decided to look for an innovative approach to teaching in such a large class. The researcher therefore resolved to use group method of teaching.

The researcher then used one month to educate the students on the prospect of studying financial accounting. Besides, the researcher enlightened them on the approaches to the study of accounting. These exercises motivated, aroused and sustained their interest in the study of accounting. Not all, the exercise created a healthy competition among the students. 
In addition to the above activities, questionnaires were drawn on the teachers to solicit their views on how to implement the intervention. The findings are analysed below.

On why the school has large class, $10 \%$ of the respondents were of the view that the vicinity of the school is densely populated. The respondents believe that a school situated at a highly populated area is likely to have a greater enrolment and hence large class size. $20 \%$ intimated that the school has great number of students as a result of its outstanding academic and moral standards. They hold the view that sweet scented soup draws people to itself, so a school with good name attracts lots of people. $70 \%$ of the respondents blame the high large class sizes on lack of infrastructural expansion and reduction in entry requirements. This is evidenced in table one below.

Table 1: The causes of high population in the school leading to large class sizes

\begin{tabular}{|l|l|l|}
\hline $\begin{array}{l}\text { responses } \\
\text { Population in the vicinity } \\
\text { of the school }\end{array}$ & $\begin{array}{l}\text { Number of teachers } \\
\begin{array}{l}\text { High academic and moral } \\
\text { standards }\end{array}\end{array}$ & $10 \%$ \\
\hline $\begin{array}{l}\text { Lack of expansion of the } \\
\text { school's facilities }\end{array}$ & 3 & $30 \%$ \\
\hline $\begin{array}{l}\text { Reduction in Entry } \\
\text { requirement \& computer } \\
\text { placement system }\end{array}$ & 4 & $40 \%$ \\
\hline TOTAL & 10 & $100 \%$ \\
\hline
\end{tabular}

When teachers were asked to give the effects of large class sizes on teaching and learning, they listed the following:

$>$ Poor classroom management

$>$ Irregular and insufficient assessment of both students and teachers

$>$ Identification of students' problems become very difficult if not impossible

$>$ Feedback of students' work delays

$>$ Most students become passive members of the class since it is difficult to involve all students in a lesson

$>$ The use of inappropriate teaching methods like lecture method

According to the table below, $70 \%$ of the respondents think that using grouping to teach in the large class helps in solving the problem such a class presents, but $30 \%$ disagree.

Table 2: Do you think putting students into smaller groups in teaching can help address the problem of large class?

\begin{tabular}{|l|l|l|}
\hline Responses & Number of respondents & percentage \\
\hline Yes & 7 & 70 \\
\hline No & 3 & 30 \\
\hline Total & 10 & 100 \\
\hline
\end{tabular}


On the question of benefits of group method of teaching the respondent gave the following as the main advantages of group method of teaching

$>$ Students' creativity is unearthed and developed

$>$ It reinforces students understanding about a concept taught since in their groups they share problems and the good students help the dull ones.

$>$ It gives every student the opportunity to participate in the lesson, and practice what is being taught. They therefore have a sense of belonging

$>$ It provides a platform the students to assess themselves and one another.

$>$ It helps learners to develop self-confidence.

\subsection{Intervention Stage}

After all these pre-intervention activities had been done, the researcher implemented the intervention.

\subsubsection{Interventions}

$>$ Discussion technique

$>$ Demonstration technique

$>$ Group method of teaching

\subsubsection{Intervention implementation}

According to Walter Bledge (1986), teaching for acquisition of skills, attitudes, and values is very complex. The learning is done by practice, involving series of activities. The learning takes place effectively only if one tries to find the solution him or herself. Therefore, to achieve learning in the category of skills, it is recommended to use the project and activity based methods of teaching. Since accounting concerns skill acquisition, the best method that offers the students opportunity to practice must be used in its presentation. This becomes very difficult when the class size is huge.

According to Farrant, (2002) grouping is an appropriate means of dealing with practical lessons. In view of this the researcher, put the students into two forms of grouping. In the first category, students were grouped according to similar ability, thus similar intellectual capabilities. In the other category, they were put into mixed ability grouping; that is brilliants were mixed with the dull ones.

During classes, the researcher introduced the lesson and then discussed the concepts with the students. A demonstration activity or practice was performed by the researcher. The students were therefore asked to move into their groups. Students were given task/problem to discuss and find solutions to them. Here the good students helped the weaker ones to get the concepts very well, that is, when mixed ability grouping is used. Where there was a problem beyond all the members of the group, the researcher's attention was drawn for further explanation and clarification. The researcher also moved round to direct and guide those with peculiar problems.

Where a task/problem was very difficult, the similar ability grouping was used. This was done so that students would be tasked according to their abilities. This was done so that slow learners were given opportunity to move at their own pace without hindering the progress of the brilliants. 


\section{Macrothink $\Lambda$ Institute"}

Students were given time frame within which to solve a problem or task. When the time elapses, they reform the class. A group was then called to present its report. The one to present the report was selected by the researcher. The selection was done randomly. This was done so that few students would not dominate the groups and also every group member would fully participate in the group's work as well as prepare him or herself for a presentation. Based on the group's performance, marks were awarded to the members of the group. Because of this, group leaders made sure that each member was well vest in the problem and its solution so that should he or she is chosen, she or he would do his/her best for the group. After presentation the groups were subjected to questioning by the class. Suggestions and corrections were made to the group's presentation by the class.

Individual assessments were also conducted intermittently to monitor the progress of the interventions and deviations were corrected. This brought a healthy competition among the groups and individuals in the class.

\subsection{Post-intervention stage}

After the intervention had been implemented for a whole term (four Months), an assessment was made to find out whether the intervention had worked. The assessment was conducted using class test, class exercises, project work and post-intervention questionnaires.

The assessment revealed amazing facts. There was dramatic improvement in the students' performance. When compared students' performance of pre-intervention with post-intervention performance, statistics showed that there had been tremendous improvement in their performance. This is evidenced in figure one below.

Figure 1

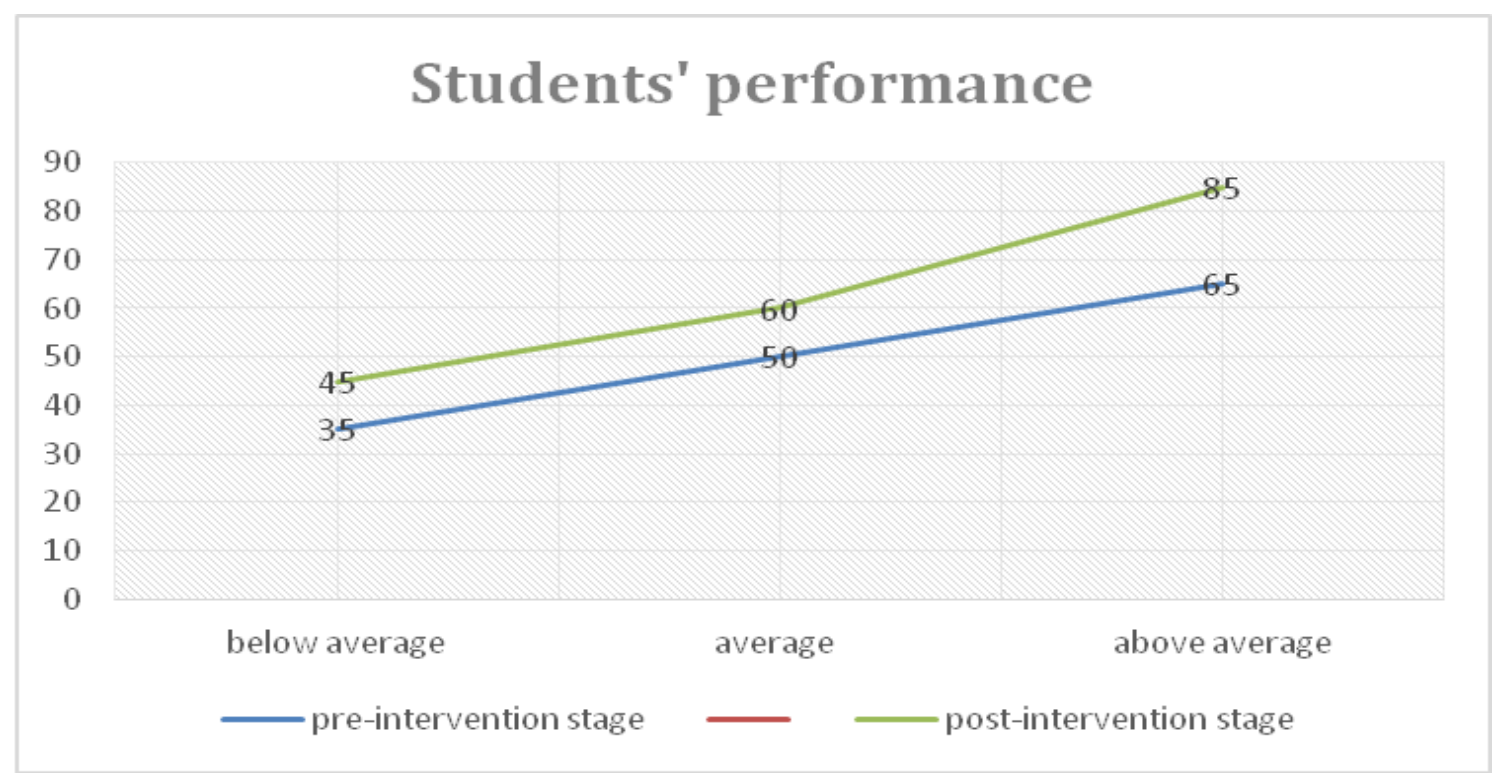

Pre-intervention and post-intervention performance

Source: Field Survey 


\section{Macrothink}

International Journal of Learning \& Development

ISSN 2164-4063

2014, Vol. 4, No. 2

The class exercises and assignments conducted after the intervention revealed that students' participation in these exercises had increased from $65 \%$ to $98 \%$. Before this intervention, only $65 \%$ on the average participated in these exercises. This shows that students were motivated through the intervention used. This is evidenced in figure two below.

Figure 2

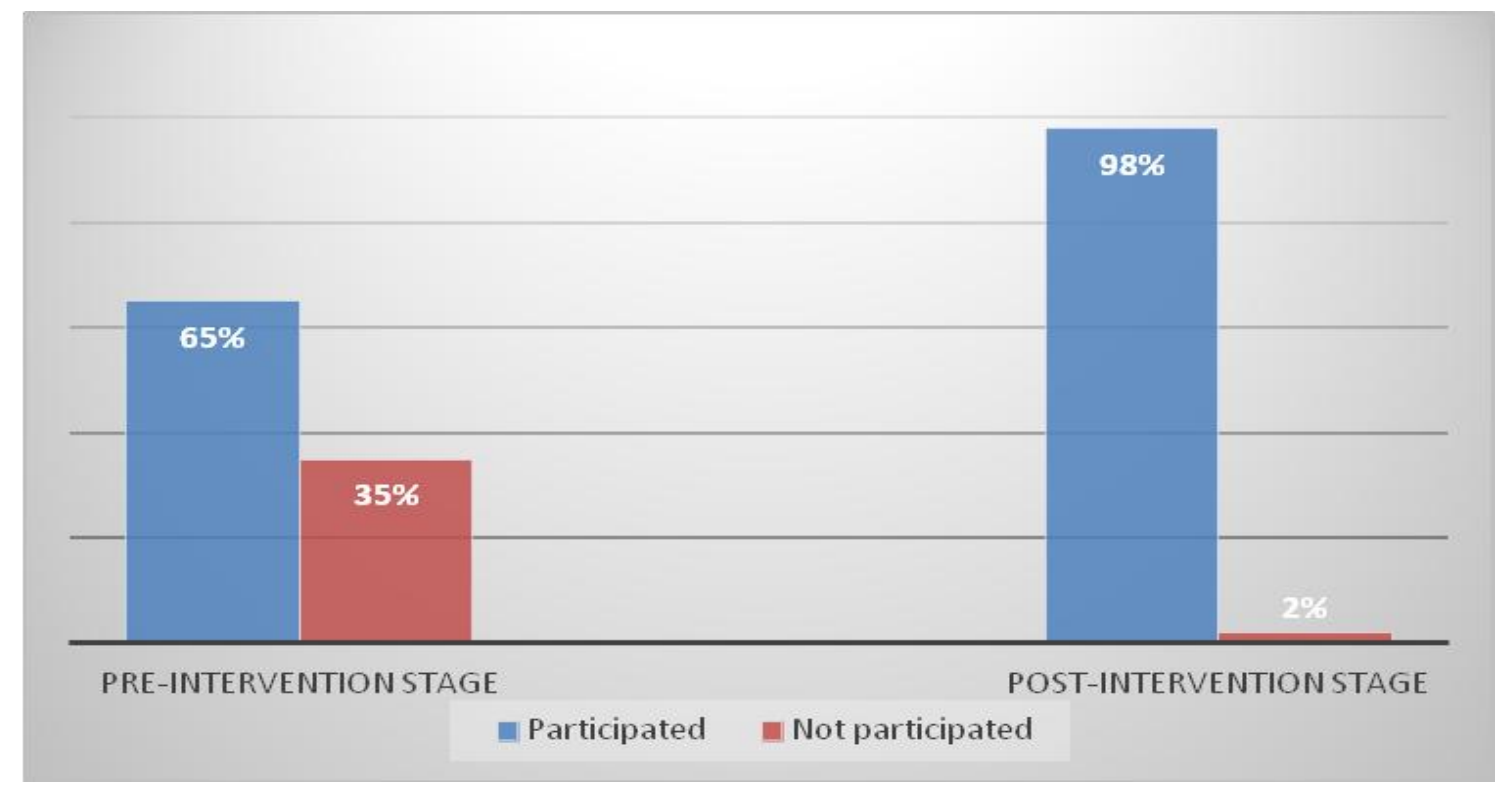

Students' participation in class exercises and assignments

Source: Field Survey

The questionnaire administered during post-intervention stage showed that all the 60 students sampled for the study, had gain high interest in financial accounting. The researcher believes that this had been so due to the innovative method used in teaching the financial accounting in such a large class. This is shown in table three below.

Table 3: Students interest in Financial Accounting

\begin{tabular}{|l|l|l|}
\hline Responses & Number of respondents & Percentage \\
\hline Yes & 60 & $100 \%$ \\
\hline No & 0 & $0 \%$ \\
\hline Total & 60 & $100 \%$ \\
\hline
\end{tabular}

Source: Field Survey

On the question of students' perception about the subject before they came to school, $68 \%$ of the respondents said they were told the subject was very difficult. $28 \%$ were of the knowledge that it was not difficult subject while $4 \%$ had no knowledge at all about the subject. However, at close of the action research, $90 \%$ of the respondents came into realization that the subject was not difficult as perceived. This is showed in figure three below. 
Figure three

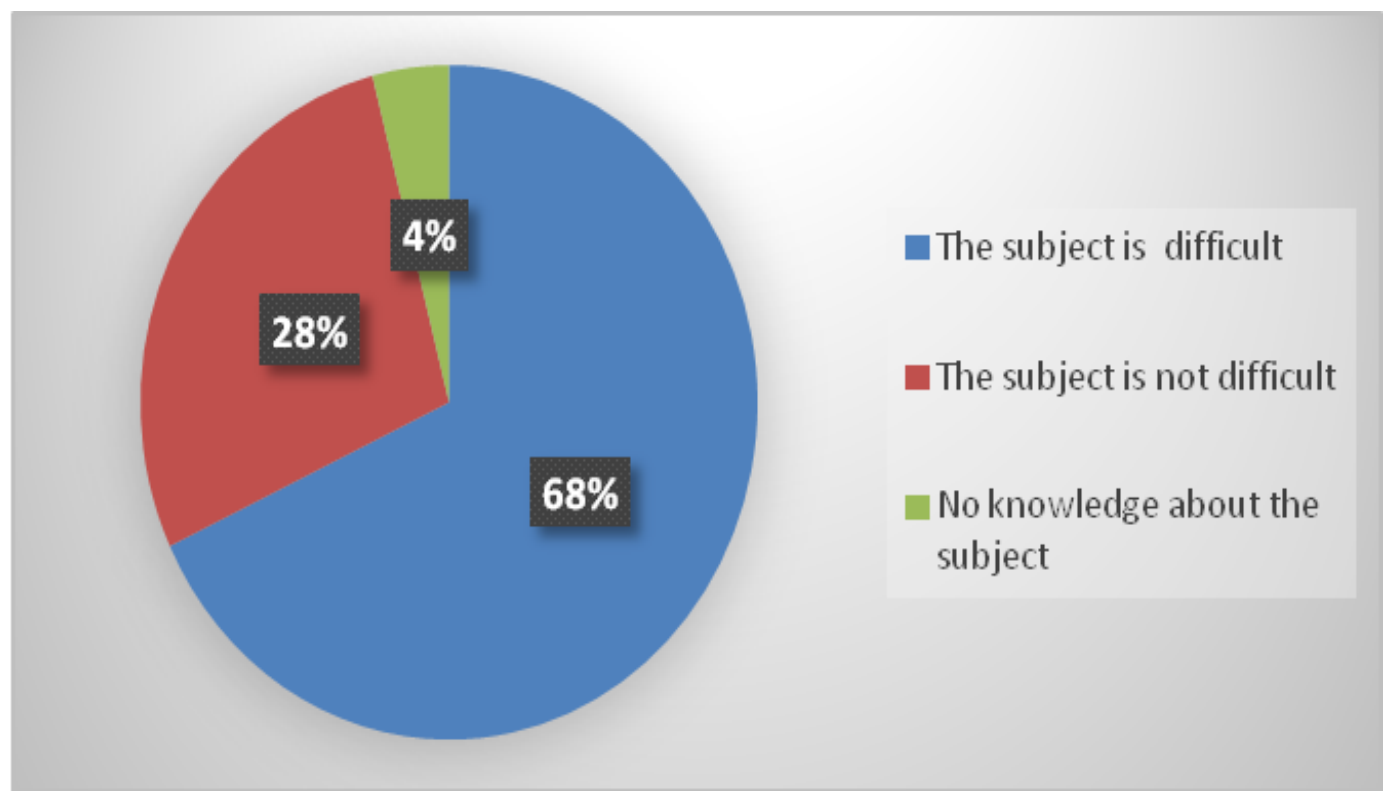

Perception about financial accounting before enrolling in the course Source: Field Survey

Figure four below indicates that 55 respondents representing $92 \%$ said they had benefited from group method of teaching used while 5 respondents representing $8 \%$ did not see any benefit the group method brought to them.

Figure 4

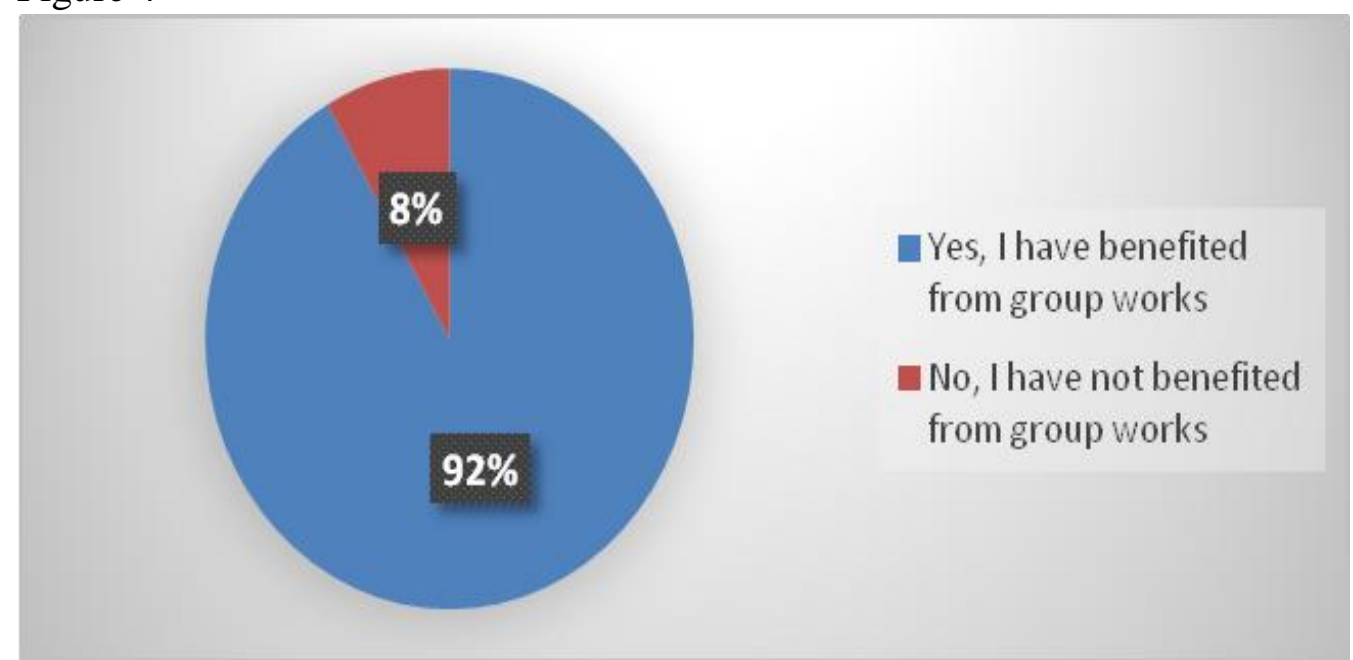

Whether respondents benefited from group method of teaching or not

Source: Field Survey

When students were asked to give the benefits they derived from group method of teaching, they listed the following:

$>$ It reinforces understanding of what was taught by the teacher

$>$ It promotes self-confidence 
$>$ It has corrected misconception about financial accounting

$>$ It offers the opportunity to develop the skill taught in class

$>$ It offers the opportunity for one to express one's self

$>$ It gives the chance to ask questions bordering one's mind

$>$ It encourages one to give of his or her best.

In addition, to the above, majority of the students interviewed, after the intervention said that the method was good and should continue and if possible used in the teaching of other subjects.

The researcher strongly believes that the change in attitude and improvement in the students' performance was as a result of the innovative approach to the teaching of financial accounting in that large class.

\subsection{Reflections, summary of findings, conclusions and recommendations}

\subsection{Reflection}

The reasons given by teachers and school authorities for high enrolment leading to large class sizes cannot be over emphasised. Education is a right not a privilege therefore no one should be deprived of such right. Every Ghanaian should be given the opportunity to develop his or her brains, hearts and hands through the school system.

In the absence of infrastructural expansion and increased staff strength, as pertained in Ghanaian schools, classes are likely to be large, in terms of number of students in a class. To make teaching and learning effective under the situation, an innovative approach to teaching must be adopted, hence the use of Group Method of Teaching so that even though classes are large, teaching is not slaughtered on the altar of comprise.

\subsection{Findings}

Analysis of data revealed that the school in question has a high enrolment leading to large classes (number of students in a class). The following were identified as causes for the high enrolment in the school: the school's vicinity is densely populated, the school has good moral and academic reputation and the school has not received any infrastructural expansions over the years.

It also came to light that the large classes are not without problems as far as teaching and learning are concerned.

The problems of large class sizes affect teaching and learning negatively. Some of the negative impacts on teaching and learning that came up during the study include: learner's creativity is stifled; evaluation system becomes less valid and effective- weakness and strength of both teachers and students are not revealed; the aims and goals of the school and education in general end up on rocks.

The study further revealed that putting students into smaller groups as a method of teaching financial accounting is the appropriate way of addressing the problem of large class sizes. As to how effectively the group method of teaching can be used, the following issues came up;

$>$ Adequate preparation and planning be made by the teacher and the students

$>$ Suitable arrangement of furniture with enough space between groups should be provided.

$>$ Good class management and control must be exercised 
$>$ Clear instructions to students as to what to do and when to do them must be observed.

$>$ Arousing students' interest in the task and implementing appropriate rewarding schemes

$>$ Students are put into mixed ability grouping for the dull to learn from the brilliants

$>$ Ability grouping are also used to allow student learn at their own pace

$>$ Enough time is given for students to finish a given task

$>$ Group works not limited to classroom work but also include project work and assignments

$>$ Proper monitor is done so that the brilliant and extroverted students do not dominate the group.

$>$ Feedback on groups' performance is made on time in order to motivate all group members to give of their best towards group achievement

$>$ Every student should be made to believe that he or she has a potential which is needed to achieve a group's goal.

From the study, group method of teaching when effectively used offers students the chance to practice what they are taught in class; develop the creative skills in them; reinforces students' understanding; lessens the teacher's work load; inculcates in students social skill like self-confidence, self-expression, leadership skills, tolerance, which are essential for individual development and nation building.

Finally, it came to light that the students appreciated the method and attest that the method was good and even appealed that is it extended to the teaching of other subjects.

Even though the researcher was the first to use the method extensively in his lesson presentations, the method is being used informally by some students in their private studies.

\subsection{Conclusion}

The sensitization programme educated the students on many issues they were ignorant of. It also motivated, aroused and sustained their interest in the subject as well as correcting the misconception they held about the subject.

The group method, though is time consuming (in terms of planning) and demanding (in relation to supervision and control), is the best way of making impact on large class.

The method brought healthy competition and helped students to develop themselves. The enthusiasm students put into learning accounting put other masters on their toes by bringing in lots of innovation into their teaching.

\subsection{Recommendations}

Since the number of students cannot be reduced because doing so means depriving some people their right to education, it is recommended that an innovative method of teaching is used in lesson presentation. By so doing teachers are going to make impact and students would benefit fully from their services.

The method is demanding therefore teachers should be motivated through incentive schemes in order to devote some private time towards the success of teaching and learning.

There should be regular forums to sensitize students about the importance of education as well as the best ways of studies to arouse and sustain their interest. 
Reward schemes should be instituted to motivate students and teachers to give of their best. It is also recommended that parents seek for extra tuition for their wards to augment what the teachers do in the classroom. Also enough time should be allocated for practical subjects when drawing time table.

Finally the government as well as the community should expand the schools' facilities, more especially the classrooms and train more teachers and also making the teaching profession more attractive.

\section{REFERENCE}

Achilles, C.M., "Class Size: New Research, Beyond STAR, Is Needed," 2008.

Anamua-Mensah, J et al (2005), Meeting the challenges of education in the twenty first century: Report of the President's Committee on Review of Education Reforms in Ghana, Adwinsa publications (Gh), Accra-Ghana, p. 61-70

Angmor, C. et al (1999), Mate Masie: Journal of the University College of Education, Winneba, Sakoa Ltd. Accra-Ghana, p. 123-129

Bledge, W. (1986), "Teaching for development”, Sedco publishing Ltd. Accra, Ghana

Bonney E., "NAGRAT Worried About Large Class Size", Daily Graphic, 25 August 2011, accessed 15th Feb. 2014

Chait, R., "Ineffective Uses of Elementary and Secondary Education Act Title II Funds," 2009.

Dorko, K., Sparks, S.D., "Setting Class-Size Limits" (Interactive Map), Education Week, 2010

Ehrenberg R.G. et al, (2011), "Class size and student achievement", Psychological Science in the Public Interest, www.sagepub.com/journals/Journal20196, accessed $15^{\text {th }}$ Feb., 2014

Farrant, J.S. (2002), "Principles and practice of education", new edition, Longman groups, U.K Ltd. United Kingdom

Hou,W.J. (1999), "Class size and determinants of learning effectiveness", Microfiche, U.S.A., P. 225-230

Imenda, S.N. et al (2004), "Educational management, administration and leadership", SAGE publications, USA, P. 195-201

Kyriacou, C. (1995), "Effective teaching in schools", Stanly Thomas publishers Ltd. United Kingdom, P. 33-35

Ornstein, A.C. and Lasley II, J.J. (2000), "Strategies for effective teaching", the Palmer press, Philadelphia, USA

Schiming R. C. (2013), "Class Size”, https://www.mnsu.edu/cetl/teachingresource

Sprinthall, A.N. and Sprinthall C.R. (1990), "Educational psychology: A developmental approach", Von Haffmann press, Inc. New York, P. 491-492.

Zainul-Deen B.D., (2011), "An assessment of Ghana's policy on quality education in the public Senior High Schools: a case study at Ahafo Ano North and South Districts", http:// dspace.knust.edu.gh:8080/jspui/handle/123456789/2081 